\title{
Multilateralism and Democracy: A Dissent Regarding Keohane, Macedo, and Moravcsik
}

\author{
Erik Gartzke and Megumi Naoi
}

\begin{abstract}
In an article printed last year in International Organization, Keohane, Macedo, and Moravcsik argued that multilateral organizations (MLO) could actually be good for democracy. We argue that KMM discount the prospect that MLO influence can be detrimental to democracies not because MLOs are "distant, elitist, and technocratic" but precisely because MLOs are highly political. International organizations have much to offer in improving the welfare of citizens and facilitating coordinations among states. They are not likely to improve procedural functions of democracies without a cost that itself is problematic for democracy.
\end{abstract}

In a recent article in this journal, Keohane, Macedo, and Moravcsik (KMM) ${ }^{1}$ take issue with the conventional wisdom that multilateral organizations (MLOs) are antidemocratic. A number of observers voice reservations about the growing capacity of international institutions to affect domestic politics. Specifically, MLOs have been accused of interfering with majoritarian democratic preferences. While KMM acknowledge that intervention weakens democratic representation, they argue that constitutional democracy consists of other functions such as deliberation and protection of minority rights. Multilateralism can produce other "democracy-enhancing constitutional functions," KMM argue, making democracy more democratic. ${ }^{2}$

We welcome KMM's provocative insight and agree that multilateralism need not be "distant, elitist, and technocratic." 3 However, KMM discount the prospect that MLO influence can be detrimental to democracies precisely because MLOs are highly political. Politicized MLOs present one of two key risks to the functioning of democracies, as they either: (1) weaken popular rule and empower special interests that consequently undermine majoritarian preferences, or (2) further empower the strong and disempower the weak, thus magnifying the politicization

We thank an anonymous reviewer and the editors of $I O$ for the comments and suggestions, which have substantially improved the manuscript. We are grateful for the participants at Tuesday lunch political economy seminar at UCSD for useful discussion and comments.

1. Keohane, Macedo, and Moravcsik 2009.

2. Ibid., 2.

3. Ibid., 1.

International Organization 65, Summer 2011, pp. 589-98 (C) 2011 by The IO Foundation. 
in domestic politics that KMM point to as a justification for MLO intervention. While MLOs are capable of protecting minorities and combating special interests as KMM emphasize, they are much more likely to do the opposite, weakening democracy or magnifying patterns of politicization already prevalent in domestic politics. Advancing MLOs as a blanket remedy for domestic tyranny without addressing these risks, as KMM do, is unbalanced.

The validity of KMM's argument hinges on three assumptions or value judgments about: (1) what makes democracy democratic, (2) the decision-making process of MLOs versus domestic governments, and (3) public goods versus distributional effects of MLOs. The first assumption concerns the relative importance of various components of democracy, such as representation, deliberation, and the protection of minority rights. The second assumption concerns an expectation that domestic politics is subject to capture by special interests, while international politics is substantially sheltered from the influence of special interests. The third assumption involves the view that MLOs largely affect the provision of public goods, but that they do not much affect the distribution of private benefits. We take issue with each point below.

\section{What Makes Democracy Democratic?: Conflating Procedure and Outcome}

KMM do not dispute that MLO intervention makes democracy less representative. ${ }^{4}$ Instead, their argument hinges on discounting the importance of representation in favor of other social benefits that they argue can be generated by MLOs. This is problematic, however, since representation is the defining and necessary attribute of democracy. ${ }^{5}$ Representation is not, as KMM argue, "only one among a number of political values to be balanced in a well-ordered constitutional democracy," since without representation democracy ceases to be democratic. ${ }^{6}$

Initiatives that erode representation should be held to a high standard in demonstrating that benefits outweigh the undisputed costs. Rather than simply providing examples where such welfare benefits may exist, KMM need to show first that limiting representation is necessary to improve citizens' welfare-that desired social benefits cannot be achieved through other means - and second, that these benefits outweigh the costs incurred by limiting representation.

As to our first point, KMM's claims rest heavily on the effects of MLOs in enhancing features that are common, but not unique or necessary components of procedural democracy, such as the rule of law, insulation and delegation, and pro-

4. MLOs and other groups also seek to improve representation through election monitoring, etc.

5. See Dahl 1971 and 1989; Przeworski, Stokes, and Manin 1999; and Przeworski et al. 2000.

6. Keohane, Macedo, and Moravcsik 2009, 5. 
tection of minority interests. ${ }^{7}$ Their claims about "democracy-enhancing" multilateralism involve the effects of improvements in domestic political processes and policy outcomes writ large, not on democratic procedure per se.

KMM also conflate democratic procedures with general welfare outcomes. ${ }^{8}$ While eventually acknowledging that "merely demonstrating multilateralism leads to more effective governance does not constitute evidence for our argument," ${ }^{9} \mathrm{KMM}$ repeatedly make the inference that since: (1) democracy makes government and/or society better, and (2) multilateralism makes government and/or society better, that (3) multilateralism makes democracy better. The third point does not logically follow from the first two, however, as what makes democracy distinct from other forms of government is the procedural emphasis on responding to the popular will. This procedural emphasis itself, as comparative studies of younger democracies have shown, does not necessarily produce good governance or improvements in social welfare. ${ }^{10}$

Nor is it clear that MLOs are necessary to achieve the social benefits KMM advocate (second point). National governments or nonstate actors, such as nongovernmental organizations (NGOs), can also assist or intervene in domestic national affairs to reduce the scope of special interest politics, improve public goods provisions, or protect minority rights. If there is nothing the authors identify that uniquely qualifies MLOs to provide these services, then we must question whether MLOs as institutions are best suited to address the tasks that KMM advocate.

Democracy promotion, for instance, is a pillar of U.S. foreign policy. Similarly, MNCs can be credited with curbing entrenched local interests, promoting minority rights (property rights), and the rule of law. ${ }^{11}$ Government and nongovernmental actors also have various means to improve public goods provisions, even in the face of strong opposition by local special interests. A voluminous literature in comparative politics has shown that democratic governments can achieve improvements through internal political and economic reforms ${ }^{12}$ and through increasing transparency. ${ }^{13}$ Autocratic governments can also improve public goods provision by expanding representation, allowing protest, and through the use of grassroots organizations. ${ }^{14}$ Thus, MLO activities are not necessary for improved public goods provision.

Nor do KMM make clear why multilateralism is necessarily superior to interventions by bilateral or unilateral organizations. Goldstein has shown that trade liberalization was achieved through unilateral and bilateral agreements under Brit-

7. See Haggard and Moon 1990; Przeworski and Limongi 1993; and Bueno de Mesquita et al. 2003.

8. We thank an anonymous reviewer for guiding us to this direction.

9. Keohane, Macedo, and Moravcsik 2009, 25.

10. See Keefer 2007; and Lake and Baum 2001.

11. Malesky 2008.

12. See Rogowski 1987; Persson and Tebellini 2003; and Haggard and Kaufman 1995.

13. Rose-Ackerman 1999.

14. See Bueno de Mesquita et al. 2003; Gandhi 2008; and Tsai 2007. 
ish hegemony, while it has been pursued multilaterally under U.S. hegemony. ${ }^{15}$ KMM themselves accept that the use of both "bilateral and multilateral forums to negotiate trade liberalization" allowed governments to build broader coalitions for free trade. ${ }^{16}$ Postwar occupations of Japan (bilateral) and Germany (multilateral) were equally successful at promoting democracy. In sum, MLOs do not appear to be necessary to accomplish the objectives set out by KMM.

As for our second point, the authors seem to believe that the will of the population is just one of several elements to be "weighted" in a cost-benefit analysis of MLO influence. However, external supervision also creates the possibility that democracy will be degraded rather than improved (see studies of multilateral peace-keeping and democratization). Broadening the role of MLOs in domestic politics necessarily involves the risk of making democracies less representative, something that KMM do not directly dispute. While KMM outline other objectives that have social value, they fail to clarify how these tradeoffs are to be evaluated.

\section{Decision-Making Processes of MLOs Versus Domestic Governments}

KMM argue that MLOs can help to counter special interest politics at the domestic level. The benefit envisioned by KMM again requires a particular sort of political world, one in which a domestic polity is captured by special interests, while MLOs remain largely apolitical. Yet, a growing international politics of special interests is already a discernible companion to expanding MLO influence. MLOs must do a better job of protecting minorities and resisting special interests than domestic institutions, given the loss of representation, greater physical and political distance, asymmetric information, bureaucratic hurdles, and problems of collective action. While KMM acknowledge the possibility that special interests influence MLO decision making, they quickly dismiss these influences. ${ }^{17}$

Special interests that have co-opted domestic politicians or institutions will surely seek to do something similar at the international level. ${ }^{18}$ Research on foreign aid, which KMM discuss, for instance, confirms this intuition. ${ }^{19}$ Svensson demonstrates that the expectation of aid inflows can be sufficient to fuel rent-seeking and

15. Goldstein 1998.

16. Keohane, Macedo, and Moravcsik 2009, 11.

17. Ibid., 16.

18. For convenience, we follow KMM in assuming that special interest politics are detrimental to democracy. However, there is abundant evidence to the contrary. Special interest politics can improve democratic decision making by reducing information asymmetry (Austen-Smith 1993), checking and monitoring bureaucrats (McCubbins and Schwartz 1984), and balancing "bad" minority interests (Becker 1983).

19. Keohane, Macedo, and Moravcsik 2009, 14-15. 
deter governments from investing in public goods. ${ }^{20}$ Alesina and Weder show that foreign aid tends to flow to corrupt governments, and that multilateral allocation is not systematically different from bilateral allocation when it comes to favoring corrupt governments. ${ }^{21}$ There is no evidence that multilateral allocation of aid is more beneficial or less politicized than bilateral allocation. ${ }^{22}$

Research on International Monetary Fund (IMF) policies and conditionality also supports the view that increasing the power of MLOs tends to favor established interests. Broz has shown that U.S. legislators' votes on the IMF financial bailout were heavily influenced by political action committee (PAC) contributions from private financial institutions. ${ }^{23}$ Gould has demonstrated that private financiers of IMF loans to developing countries influence the terms of conditionality agreements. ${ }^{24}$ Stone reports that U.S. efforts to constrain IMF conditionality are prevalent especially among vulnerable developing countries. ${ }^{25}$ These studies suggest that MLOs could expand, rather than reduce the power of special interests.

One area in which MLOs and domestic politics could differ is in the role of money. Domestic special interests typically make political donations to legislators and political parties in the expectation of some quid quo pro. ${ }^{26}$ This is the very kind of influence peddling that many democracy advocates wish to control. In contrast, MLOs offer no formal channel through which special interests can legally influence decision making. Yet, the fact that officials of MLOs do not formally run for office does not prevent money from entering politics.

A number of scholars have examined foreign aid as a means of "buying" votes in the United Nations ${ }^{27}$ and at the International Whaling Commission. ${ }^{28}$ In addition to these overt channels in which member states use money to influence MLO decisions, bribery and corruption are endemic to bureaucracies. Scandal involving UN officials supervising the Iraqi Oil-for-Food Program illustrates the risks of giving MLOs control over lucrative issues or valuable resources.

If money also influences politics at MLOs, then how should this process be regulated to achieve improved citizen welfare and protection of minority rights? In democratic politics, governments can regulate political donations and elections can discipline dishonest politicians or officials. Regulation of MLOs is much harder as issue-linkages are prevalent across institutions with overlapping memberships and jurisdictions, such as foreign aid and UN voting. The majority of MLOs also

20. Svensson 2000 .

21. Alesina and Weder 2002.

22. This does not contradict the result in Milner 2006 — which KMM discuss extensively-that public skepticism about aid shifts allocation from bilateral to multilateral channels. Milner's thesis involves public perception, not whether multilateral agencies actually are less corrupt or more effective.

23. Broz 2005.

24. Gould 2006.

25. Stone 2008 .

26. Grossman and Helpman 1994.

27. See Kuziemko and Werker 2006; and Dreher, Nunnenkamp, and Thiele 2008.

28. Schaffer 2007. 
lack competitive elections to punish corrupt officials. Regulation and discipline of MLOs thus falls back on the same national governments supervised by MLOs.

KMM's argument about preferences and the decision-making process of MLOs versus local governments also poses a logical conundrum. For interventions to be effective, MLOs must achieve policy goals that domestic governments would not have achieved autonomously. ${ }^{29}$ The policy preferences of domestic governments and MLOs thus need to be in tension. Yet, the greater this tension, the more domestic interests benefit from resisting the efforts of the MLO. One should expect to see increased political activities by domestic interests to prevent, co-opt, or undermine MLO reforms as MLOs become more salient in domestic politics.

Efforts to undermine the welfare-improving policies of MLOs can take several forms. First, powerful states and well-resourced special interests can thwart or reshape MLO initiatives. This is possible either due to the formal structure of decision making at MLOs, which tends to protect status-quo powers (for example, the UN and IMF), or because powerful actors are able to stall initiatives informally. Second, MLOs with growing but finite enforcement powers are likely to impose their rules where they are able. For example, WTO treaty enforcement and IMF financial oversight effectively favor wealthy countries over the poor. ${ }^{30}$

MLOs are born of politics. Powerful interests create international institutions to increase the welfare and stability of the founders. ${ }^{31}$ When founder states allow MLOs to influence domestic politics, it is with the intent of disproportionately affecting less powerful countries. Selective intervention by MLOs creates an unlevel playing field by undermining majoritarian interests in weaker states, while leaving powerful special interests largely unaffected.

Up to this point, we have assumed that MLOs are well-intentioned. Yet, MLOs often overstep, ${ }^{32}$ make errors common to large bureaucracies, ${ }^{33}$ or even impose harm. ${ }^{34}$ MLOs have inferior information about local conditions, compared with local governments. According to Keohane and Ostrom, "[g]overnment policies that have ignored the local knowledge of participants or underestimated their abilities to solve collective-action problems have done great damage." 35 What mechanisms will protect citizens from MLO expropriations or errors? KMM devote almost no attention to the control or regulation of the powerful MLOs they advocate. $^{36}$

29. See Dahl's definition of power 1961.

30. See Busch and Reinhardt 2002; and Satyanath 2006.

31. Stone 2008.

32. See Wade and Veneroso 1998; and Stiglitz 2002.

33. Haas 1983.

34. Barnett and Finnemore 2004.

35. Keohane and Ostrom 1995, 21.

36. KMM cite James Madison as support for their claim that bigger is better for democracy (Hamilton, Madison, and Jay 1961, 83). Madison was concerned about tyrannical permanent majorities that he hoped would be checked by elections on two levels (the very mechanism KMM discount). Modern scholars use institutions as mechanisms to prevent cycling, creating permanent winners. 


\section{The Governments and MLOs: General Welfare Versus Distributional Effects}

The normative rationale for international organizations is that they improve the welfare of member states and citizens through the provision of social benefits that are otherwise unobtainable due to various barriers to cooperation or collective action. MLOs protect the global commons, regulate pollution, and lower trade restrictions. While concerns persist, the appeal of MLOs as public goods providers is logically persuasive and normatively compelling.

The growing resources and power of MLOs mean that they have more opportunities to redistribute wealth at both the domestic and international level. ${ }^{37} \mathrm{KMM}$ focus on the public goods functions of MLOs, not on their distributional effects. This imbalance strikes us as strange, again, precisely because KMM's argument hinges on the ability of MLOs to assign domestic winners and losers. Although KMM accept that MLOs will develop a distributional capacity as part of their ability to influence domestic politics, they somehow assume this power as benign. ${ }^{38}$

The distributional power of MLOs poses a double-edged sword for reformers. Once MLOs command the ability to redistribute within and between societies, interventions will create new winners and losers. This is so even when MLOs have no innate politicized incentives. ${ }^{39}$ As long as MLOs generate distributional consequences, interested parties will seek to influence the decision making of MLOs. To achieve the social benefits outlined by KMM, MLOs will have to resist not only powerful vested interests that seek to block MLO reforms, but they must also avoid capture by the newly emerging beneficiaries created by their own reform efforts. $^{40}$

One way of assisting MLOs in resisting such influences is to limit the scope of their activities to areas where MLO regulations improve public goods provisions without generating much in the way of distributional consequences. However, this means that the ability of MLOs to alter the domestic distribution of power needs to remain fairly limited. This in turn undermines KMM's argument about the potential for MLOs to counter domestic special interests. The capacity of MLOs to redistribute wealth begs the question of how decision-making procedures at MLOs and domestic governments affect redistribution. In democracies, one of the major constraints on redistribution is the vote mechanism. ${ }^{41}$ Redistribution by MLOs can also be regulated through representatives in the governing bodies of the organization. However, these MLO representatives are typically appointed by the same officials and governments that MLOs are supposed to regulate and reform. The mechanism of "sanction at the ballot box" thus works at cross-purposes to KMM's

37. Goldstein and Martin 2000.

38. For an objection, see Oatley and Nabors 1998 on the Basle Accord.

39. Barro and Gordon 1983.

40. Hellman 1998.

41. Meltzer and Richard 1981. 
objectives. If instead MLOs are autonomous from domestic citizens and policymakers, then MLOs are not accountable, and MLOs themselves are undemocratic.

\section{Misuse of Empirical Cases}

KMM's use of empirical examples also poses concerns. KMM offer two cases intended to illustrate their claim that multilateralism can empower weak and diffused interests: the Reciprocal Trade Agreements Act (RTAA) of 1934, which aided consumers by lowering tariffs, and a WTO ruling requiring European countries to compensate exporters when they restrict imports of genetically modified agricultural products, which, KMM claim, gave consumers greater access to cheaper food. Use of the RTAA case is problematic for two reasons:

1. The RTAA was a domestic law that allowed U.S. presidents to sign bilateral trade agreements. Thus, it did not originate as a multilateral endeavor.

2. Scholarly convention is that the RTAA empowered exporters and organized interests who stood to benefit from free trade. Although the liberalization achieved under the RTAA subsequently benefited consumers, the evidence is clear that RTAA reform was intended to empower free-trade-oriented organized interests. ${ }^{42}$

Similarly, the WTO ruling can be seen as a triumph of well-resourced U.S. agricultural producers who export commodities with potential health risks at the expense of consumer welfare. These examples suggest that MLOs may help diffused interests, but only as a by-product of intended assistance to powerful interests.

Rather than making democracy more "democratic," MLOs provide resources and opportunities to fuel the kind of special interest politics KMM clearly oppose. At least in this instance, the conventional wisdom appears fairly wise; MLOs can accomplish many admirable objectives, but they are bound to weaken, rather than augment, domestic democracy.

In concluding, we suggest promising venues for future research. First, scholars should focus on how domestic politics and institutions "filter" the distributional effects of policies adopted by multilateral organizations. This "filtering" can occur in ways that mobilize organized interests or diffused interests via different electoral systems, or, by empowering economic winners or losers via partisanship in the government. ${ }^{43}$ Identifying domestic conditions under which multilateral interventions mobilize some groups over others will help to clarify our debate. Second, scholars should go beyond testing the effect of multilateralism on general welfare outcomes and look at its effect on political processes and decision-making procedures more directly. This line of inquiry allows researchers to identify con- 
ditions under which multilateralism leads to more insulation or capture of domestic governments by special interests.

\section{References}

Alesina, Alberto, and Beatrice Weder. 2002. Do Corrupt Governments Receive Less Foreign Aid? American Economic Review 92 (4):1126-37.

Austen-Smith, David. 1993. Information and Influence: Lobbying for Agendas and Votes. American Journal of Political Science 37 (3):799-833.

Barnett, Michael N., and Martha Finnemore. 2004. Rules for the World: International Organizations in Global Politics. Ithaca, N.Y.: Cornell University Press.

Barro, Robert J., and David B. Gordon. 1983. Rules, Discretion, and Reputation in a Model of Monetary Policy. Journal of Monetary Economics 12 (1):101-21.

Becker, Gary S. 1983. A Theory of Competition Among Pressure Groups for Political Influence. Quarterly Journal of Economics 98 (3):371-400.

Broz, J. Lawrence. 2005. Congressional Politics of International Financial Rescues. American Journal of Political Science 49 (3):479-96.

Bueno de Mesquita, Bruce, Alastair Smith, Randolph M. Siverson, and James D. Morrow. 2003. The Logic of Political Survival. Cambridge, Mass.: MIT Press.

Busch, Marc L., and Eric Reinhardt. 2002. Testing International Trade Law: Empirical Studies of GATT/ WTO Dispute Settlement. In The Political Economy of International Trade Law: Essays in Honor of Robert E. Hudec, edited by Daniel L. M. Kennedy and James D. Southwick, 457-81. New York: Cambridge University Press.

Dahl, Robert A. 1961. Who Governs? Democracy and Power in an American City. New Haven, Conn.: Yale University Press.

- 1971. Polyarchy: Participation and Opposition. New Haven, Conn.: Yale University Press. 1989. Democracy and Its Critics. New Haven, Conn.: Yale University Press.

Dreher, Axel, Peter Nunnenkamp, and Rainer Thiele. 2008. Does U.S. Aid Buy UN General Assembly Votes? A Disaggregated Analysis. Public Choice 136 (1-2):139-64.

Gandhi, Jennifer. 2008. Political Institutions under Dictatorship. New York: Cambridge University Press.

Gilligan, Michael J. 1997. Empowering Exporters: Reciprocity, Delegation, and Collective Action in American Trade Policy. Ann Arbor: University of Michigan Press.

Goldstein, Judith. 1998. International Institutions and Domestic Politics: GATT, WTO, and the Liberalization of International Trade. In The WTO as an International Organization, edited by Anne O. Krueger, 133-60. Chicago: Chicago University Press.

Goldstein, Judith L., and Lisa Martin. 2000. Legalization, Trade Liberalization, and Domestic Politics: A Cautionary Note. International Organization 54 (3):603-32.

Gould, Erica R. 2006. Money Talks: The International Monetary Fund, Conditionality and Supplementary Financiers. Stanford, Calif.: Stanford University Press.

Grossman, Gene M., and Elhanan Helpman. 1994. Protection for Sale. The American Economic Review 84 (4):833-50.

Haas, Ernst B. 1983. Regime Decay: Conflict Management and International Organizations, 19451981. International Organization 37 (2):189-256.

Haggard, Stephan. 1988. The Institutional Foundations of Hegemony: Explaining the Reciprocal Trade Agreements Act of 1934. International Organization 42 (1):91-119.

Haggard, Stephan, and Robert R. Kaufman. 1995. The Political Economy of Democratic Transitions. Princeton, N.J.: Princeton University Press.

Haggard, Stephan, and Chung-In Moon. 1990. Institutions and Economic Policy: Theory and a Korean Case Study. World Politics 42 (2):210-37. 
Hamilton, Alexander, James Madison, and John Jay. 1961 [1787]. The Federalist Papers. New York: New American Library.

Hellman, Joel. 1998. Winners Take All: The Politics of Partial Reform in Postcommunist Transitions. World Politics 50 (2):203-34.

Keefer, Philip. 2007. Clientelism, Credibility, and the Policy Choices of Young Democracies. American Journal of Political Science 51 (4):804-21.

Keohane, Robert O., Stephen Macedo, and Andrew Moravcsik. 2009. Democracy-Enhancing Multilateralism. International Organization 63 (1):1-31.

Keohane, Robert O., and Elinor Ostrom. 1995. Local Commons and Global Interdependence: Heterogeneity and Cooperation in Two Domains. London: Sage.

Kuziemko, Ilyana, and Eric Werker. 2006. How Much Is a Seat on the Security Council Worth? Foreign Aid and Bribery at the United Nations. Journal of Political Economy 114 (5):905-30.

Lake, David, and Matthew A. Baum. 2001. The Invisible Hand of Democracy: Political Control and the Provision of Public Services. Comparative Political Studies 34 (6):587-621.

Malesky, Edmund J. 2008. Straight Ahead on Red: How Foreign Direct Investment Empowers Subnational Leaders. Journal of Politics 70 (1):97-119.

McCubbins, Mathew D., and Thomas Schwartz. 1984. Congressional Oversight Overlooked: Police Patrols Versus Fire Alarms. American Journal of Political Science 28 (1):165-79.

Meltzer, Allan H., and Scott F. Richard. 1981. A Rational Theory of the Size of Government. Journal of Political Economy 89 (5):914-27.

Milner, Helen V. 2006. Why Multilateralism? Foreign Aid and Domestic Principal-Agent Problems. In Delegation and Agency in International Organizations, edited by Darren G. Hawkins, David A. Lake, Daniel L. Nielson, and Michael J. Tierney, 107-39. Cambridge: Cambridge University Press.

Naoi, Megumi. 2009. Shopping for Protection: The Politics of Choosing Trade Instruments in a Partially Legalized World. International Studies Quarterly 53 (2):421-44.

Oatley, Thomas, and Robert Nabors. 1998. Redistributive Cooperation: Market Failure, Wealth Transfers, and the Basle Accord. International Organization 52 (1):35-54.

Persson, Torsten, and Guido Tebellini. 2003. The Economic Effects of Constitutions. Cambridge, Mass.: MIT Press.

Przeworski, Adam, Michael E. Alvarez, José Antonio Cheibub, and Fernando Limongi. 2000. Democracy and Development: Political Institutions and Well-Being in the World, 1950-1990. Cambridge: Cambridge University Press.

Przeworski, Adam, and Fernando Limongi. 1993. Political Regimes and Economic Growth. Journal of Economic Perspectives 7 (3):51-69.

Przeworski, Adam, Susan C. Stokes, and Bernard Manin, eds. 1999. Democracy, Accountability, and Representation. Cambridge: Cambridge University Press.

Rogowski, Ronald. 1987. Political Cleavages and Changing Exposure to Trade. American Political Science Review 81 (4):1121-37.

Rose-Ackerman, Susan. 1999. Corruption and Government: Causes, Consequences, and Reform. Cambridge: Cambridge University Press.

Satyanath, Shanker. 2006. Globalization, Politics, and Financial Turmoil: Asia's Banking Crisis. New York: Cambridge University Press.

Schaffer, Frederic C., ed. 2007. Elections for Sale: The Causes and Consequences of Vote Buying. Boulder, Colo.: Lynne Rienner.

Stiglitz, Joseph E. 2002. Globalization and Its Discontents. New York: Norton.

Stone, Randall W. 2008. The Scope of IMF Conditionality. International Organization 62 (4):589-620.

Svensson, Jakob. 2000. Foreign Aid and Rent-Seeking. Journal of International Economics 51 (2): 437-61.

Tsai, Lily L. 2007. Solidary Groups, Informal Accountability, and Local Public Goods Provision in Rural China. American Political Science Review 101 (2):355-72.

Wade, Robert, and Frank Veneroso. 1998. The Asian Crisis: The High Debt Model Versus the Wall Street-Treasury-IMF Complex. New Left Review I/228:3-22. 